\title{
PERAN ORANG TUA TUNGGAL DALAM MEMBIMBING ANAK REMAJA MENCAPAI KUALITAS HIDUP DI GEREJA KIBAID KLASIS MAKASSAR
}

\author{
Yuliana Banni \\ sttjaffraymakassar@yahoo.co.id \\ Elisabeth Selfina \\ sttjaffraymakassar@yahoo.co.id
}

\begin{abstract}
ABSTRAK
Berdasarkan pokok masalah di atas, maka yang menjadi tujuan penulis sebagai sasaran dalam penulisan karya ilmiah ini, yaitu:Pertama, agar setiap orang tua tunggal memahami peranan mereka dalam membimbing anak remaja.Kedua, agar anak-anak remaja dari orang tua tunggal termotivasi untuk mencapai kualitas hidup.

Dalam karya ilmiah ini, penulis menggunakan metode penelitian sebagai berikut:Pertama, metode kepustakaan yaitu penulis mencari dan mengumpulkan informasi melalui buku-buku yang berkaitan dengan karya ilmiah ini. Menurut asal katanya kepustakaan berasal dari kata dasar "pustaka", yang berarti (1) buku-buku kesusastraan; (2) daftar kitab yang dipakai sebagai sumber acuan untuk mengarang, dan sebagainya; atau (3) semua buku atau karangan dan tulisan mengenai suatu bidang ilmu, topik, gejala atau kejadian. ${ }^{1}$ Kedua, penulis menggunakan wawancara kepada orangorang yang dapat melengkapi data yang diperlukan dalam karya ilmiah ini. Wawancara ialah (l) tanya jawab dengan seseorang (pejabat dsb) yang diperlukan untuk dimintai keterangan atau pendapatnya mengenai suatu hal, untuk dimuat dalam surat kabar, disiarkan melalui radio, atau ditayangkan pada layar televisi atau untuk kepentingan penulisan karya ilmiah; (2) tanya jawab direksi (kepala personalia, kepala humas) perusahaan dengan pelamar pekerjaan; (3) tanya jawab peneliti dengan narasumber. ${ }^{2}$

Berdasarkan pembahasan penulis di atas, maka dapat dibuat kesimpulan sebagai berikut: orang tua tunggal atau single parent Persekutuan Kaum Wanita KIBAID Klasis Makassar adalah mereka yang menyadari sepenuhnya tugas mereka sebagai orang tua yang berperan sebagai ayah dan juga ibu yang mengatur segala sesuatunya di rumah dan bertanggung jawab sepenuhnya kepada anak-anak mereka. Orang Tua tunggal atau single parent Persekutuan Kaum Wanita KIBAID Klasis Makassar sudah sangat baik dalam menjalankan fungsinya sebagai orang tua tunggal bagi anak-anaknya. Sehingga anak-anak bertumbuh dengan baik dalam mencapai kualitas hidup mereka.
\end{abstract}

Kata Kunci: Orang Tua Tunggal, Anak Remaja, dan Kualitas Hidup

\footnotetext{
${ }^{1}$ Arti kata.com, Definisi Kepustakaan, diakses tanggal 26 Juni 2011 tersedia di http://www.artikata. com/ arti-374721-kepustakaan.html.

${ }^{2}$ Ibid. tersedia di http://www.artikata. com/arti-356604-wawancara.html.
} 


\section{PENDAHULUAN}

\section{Latar Belakang Masalah}

Satu hal yang pasti bahwa di tengah-tengah masyarakat dapat ditemukan banyak orang tua tunggal yang sedang mengalami hidup yang penuh pergumulan dan tantangan dalam membimbing anak remaja mereka sampai mencapai kualitas hidup.

Surya Kusuma memaparkan orang tua tunggal (single parent) adalah istilah yang sudah sangat akrab bagi sebagian orang, secara sederhana orang tua tunggal (single parent) adalah orang tua tunggal yang berperan ganda dalam membesarkan seorang anak. Bisa berperan sebagai ayah sekaligus sebagai ibu. ${ }^{3}$

Pada umumnya anggapan masyarakat bahwa orang tua tunggal tidak dapat mendidik anaknya sebagaimana orang tua biasa (lengkap), seperti yang diungkapkan oleh Christella, "Pada umumnya orang mengira bahwa seorang yang memelihara anak-anak tanpa bantuan orang tua yang satunya akan mengalami kegagalan dan kehancuran, anak-anaknya akan berantakan dan sebagainya." 4

Pernyataan di atas memang ada benarnya, tetapi sebaliknya masih banyak orang tua tunggal yang telah berhasil membimbing anak-anaknya. Archibald D. Hart menyatakan banyak orang tua tunggal bertanya kepadanya: "Dapatkah saya menjadi orang tua tunggal yang efektif sama seperti kalau keluarga saya lengkap? Jawabnya ya, pasti dan jelas, tetapi hal itu memang dibutuhkan kerja keras."

Selanjutnya sekalipun orang tua diperhadapkan dengan banyak pergumulan atau tantangan, perlu adanya usaha keras, harapan serta keyakinan bahwa anak yang Tuhan hadirkan dalam kehidupan keluarga orang tua tunggal tidak lebih buruk atau kurang beruntung, dibanding anak-anak dari keluarga lengkap (utuh), sebab anak-anak dari keluarga orang tua tunggal banyak yang berhasil menjadi orang hebat, dan biasanya mereka dibesarkan hanya oleh seorang ibu saja. ${ }^{6}$

Manati Zega memaparkan, bahwa "Menjadi orang tua, tidak mudah dijalani apalagi dilakoni sendiri. Keluarga utuh saja sangat kesulitan menjalani dan menghadapi berbagai permasalahan yang ada, apalagi keluarga orang tua tunggal (keluarga tidak utuh)."”

\footnotetext{
${ }^{3}$ Surya Kusuma, Bila Terpaksa Menjasi Single Parent. Jakarta: Bahana, Mei 2010, 43

${ }^{4}$ Christella Ds, Sendiri Tidak Sepi. Denpasar: Yayasan Ave Maris Stella, April 2010), 133.

${ }^{5}$ Archibald D. Hart, Menolong Anak Korban Perceraian. Bandung: Kalam Hidup, 2002. 208.

${ }^{6}$ Ibid.

${ }^{7}$ Manati Zega, Spritual Insight, Bahana, Mei 2010.
} 
Dalam membimbing dan mengasuh anak remaja selalu merupakan tantangan dan pergumulan yang menuntut, hal itu tidak mudah dilakukan oleh keluarga tunggal, orang tua yang lengkap (utuh) saja, biasanya merasa gagal seperti yang diungkapkan oleh Archibald D. Hart: "Mengasuh anak sendiri merupakan tugas yang jauh lebih sulit daripada ketika anda mempunyai pasangan." ${ }^{8}$

Ketika seorang ibu ditinggalkan oleh seorang suaminya karena perceraian atau kematian, keadaan membawa perubahan status sosial yang sangat mempengaruhi psikologi ibu dan anak-anaknya. Perubahan sosial itu seringkali membawa keluarga orang tua tunggal merasa kurang percaya diri, merasa kurang mampu oleh keterbatasan pada dirinya dalam menjalani hidup kedepan, karena hilang (ketidak hadiran) seorang yang berperan sebagai pemimpin (Ayah) di dalam keluarga orang tua tunggal.

Manati Zega mengatakan: "Bagi orang tua tunggal yang dengan rela melibatkan Tuhan dalam setiap keadaan tersedia janji pemeliharaan Tuhan baginya." Mazmur 68:6, "Bapa bagi anak yatim dan pelindung bagi para janda, itulah Allah di kediaman-Nya yang kudus." Allah menempatkan diri sebagai Bapa bagi anak-anak yatim, Allah menjadi pelindung bagi janda. ${ }^{9}$

Bertolak dari apa yang dikemukakan di atas, maka penulis ingin menuangkan dalam satu karya ilmiah yang berjudul: "PERAN ORANG TUA TUNGGAL DALAM MEMBIMBING ANAK REMAJA MENCAPAI KUALITAS HIDUP DI GEREJA KIBAID KLASIS MAKASSAR."

\section{Pokok Masalah}

Di dalam penulisan karya ilmiah ini, ada dua hal yang menjadi pokok masalah sehubungan dengan pembahasan penulis yaitu:

Pertama, Bagaimana peran orang tua tunggal dalam membimbing anak remaja untuk mencapai kualitas hidup.

Kedua, Bagaimana dampak sosial dan psikologi terhadap anak remaja yang (diasuh) dibimbing oleh orang tua tunggal.

\section{Tujuan Penulisan}

Berdasarkan pokok masalah di atas, maka yang menjadi tujuan penulis sebagai sasaran dalam penulisan karya ilmiah ini, yaitu:

Pertama, agar setiap orang tua tunggal memahami peranan mereka dalam membimbing anak remaja.

Kedua, agar anak-anak remaja dari orang tua tunggal termotivasi untuk mencapai kualitas hidup.

${ }^{8}$ Archibald D. Hart, Menolong Anak Korban Perceraian. Bandung: Kalam Hidup, 2002. 208.

${ }^{9}$ Manati Zega, Spritual Insight, Bahana, Mei, 2010. 


\section{Manfaat Penulisan} penulis.

Pertama, dapat menjadi sumber pengetahuan dan pegangan bagi

Kedua, dapat menjadi sumber pengetahuan bagi orang tua tunggal dalam membimbing anak remaja.

Ketiga, agar dapat memenuhi salah satu persyaratan Bidang Akademik dalam menyelesaikan program sarjana di Sekolah Tinggi Teologia Jaffray Makassar.

\section{Batasan Penulisan}

Ruang lingkup pembahasan dalam karya ilmiah ini yaitu berfokus pada peran orang tua tunggal yaitu ibu atau janda dalam membimbing anak remaja umur 12-18 tahun untuk mencapai kualitas hidup di persekutuan kaum wanita gereja KIBAID Klasis Makassar.

\section{Metode Penelitian}

Dalam karya ilmiah ini, penulis menggunakan metode penelitian sebagai berikut:

Pertama, metode kepustakaan yaitu penulis mencari dan mengumpulkan informasi melalui buku-buku yang berkaitan dengan karya ilmiah ini. Menurut asal katanya kepustakaan berasal dari kata dasar "pustaka", yang berarti (1) buku-buku kesusastraan; (2) daftar kitab yang dipakai sebagai sumber acuan untuk mengarang, dan sebagainya; atau (3) semua buku atau karangan dan tulisan mengenai suatu bidang ilmu, topik, gejala atau kejadian. ${ }^{10}$

Kedua, penulis menggunakan wawancara kepada orang-orang yang dapat melengkapi data yang diperlukan dalam karya ilmiah ini. Wawancara ialah (l) tanya jawab dengan seseorang (pejabat dsb) yang diperlukan untuk dimintai keterangan atau pendapatnya mengenai suatu hal, untuk dimuat dalam surat kabar, disiarkan melalui radio, atau ditayangkan pada layar televisi atau untuk kepentingan penulisan karya ilmiah; (2) tanya jawab direksi (kepala personalia, kepala humas) perusahaan dengan pelamar pekerjaan; (3) tanya jawab peneliti dengan narasumber. ${ }^{\text {ll }}$

Ketiga, menggunakan angket untuk memperoleh infomasi jelas dari beberapa orang tua tunggal dan anak remaja dari orang tua tunggal. Angket ialah "daftar pertanyaan tertulis mengenai masalah tertentu dengan ruang untuk jawaban bagi setiap pertanyaan." 12

\footnotetext{
${ }^{10}$ Arti kata.com, Definisi Kepustakaan, diakses tanggal 26 Juni 2011 tersedia di http://www.artikata. com/ arti-374721-kepustakaan.html.

${ }^{11}$ Ibid. tersedia di http://www.artikata. com/arti-356604-wawancara.html.

${ }^{12}$ Ibid. tersedia di http://www.artikata.com/arti-31904l-angket.html.
} 
Keempat, mengutip beberapa artikel lewat pemanfaatan media internet yang kesemuanya diharapkan dapat saling melengkapi serta berkaitan erat dengan penulisan ini. Artikel adalah karya tulis lengkap, misalnya laporan berita atau esai dalam majalah, surat kabar, dan media cetak lainnya. ${ }^{13}$

Kelima, melalui observasi kepada orang tua tunggal dan anaknya di Persekutuan Wanita Gereja Kibaid Klasis Makassar. Observasi adalah (1) peninjauan secara cermat sebelum melakukan praktik di suatu tempat; (2) mengawasi dengan teliti dan mengamati. ${ }^{14}$

\section{METODOLOGI PENELITIAN}

Dalam bagian ini penulis akan menguraikan tahap yang ditempuh guna memperoleh data yang akurat. Namun sebelum penulis menguraikan beberapa langkah dalam penelitian ini, penulis akan menjelaskan keadaan objek penelitian dalam karya ilmiah ini sebagai berikut:

\section{Gambaran Umum Lokasi Penelitian}

\section{Sejarah Singkat Berdirinya Gereja Kerapatan Injil Bangsa Indonesia} (KIBAID)

Gereja KIBAID didirikan pada tanggal 4 Juli 1936 di Makassar dan mendapat Badan Hukum pada tangal 4 November 1949 dari Menteri Djistisi Indonesia Timur No. A. 15/1/33/1949 dengan Nama Kerapatan Injil Bangsa Toraja yang operasionalnya meliputi seluruh Indonesia. Berdasarkan keputusan konferensi pada tanggal 27-28 September 1961 di Makassar, nama Kerapatan Injil Bangsa Toraja (KIBAT). Diubah menjadi Gereja Kerapatan Injil Bangsa Indonesia (KIBAID) dengan Akta Notaris No. 21 tanggal 6 Juni 1980 tentang "Perubahan Nama dari gereja KIBAT menjadi Gereja KIBAID." Untuk menjadi pegangan dalam melaksanakan visi dan misinya sesuai dengan undang-undang No. 8 tahun 1985, Gereja KIBAID sebagai salah satu organisasi kemasyarakatan yang bergerak di bidang keagamaan telah mendaftar ulang pada Dirjen Bimas Kristen Prostestan Departemen Agama No. 159 tanggal 25 Juli 1989. Kemudian Gereja KIBAID mendapat penunjukan dari Badan Pertanahan Nasional sebagai Badan

\footnotetext{
${ }^{13}$ Arti kata.com, Definisi Kepustakaan, diakses tanggal 26 Juni 201l, tersedia di http://www.artikata. com/arti-319650-artikel.html.

${ }^{14}$ Arti kata.com, Definisi Kepustakaan, diakses tanggal 20 Mei 201l, tersedia di http://www.artikata.com/arti-342618-observasi.html.
} 
Hukum yang dapat mempunyai hak miliki atas tanah dengan No. 41VIII/1995 tanggal 19 Oktober $1995 .^{15}$

\section{Persekutuan Kaum Wanita (PKW) Gereja KIBAID}

Kaum perempuan Gereja KIBAID sebenarnya sudah memulai persekutuannya sejak gereja KIBAID berdiri namun belum terkoordinir secara nasional. Sebelum tahun 1968 kaum perempuan di Toraja dan di Makassar sudah di koordinir secara wilayah. Di Toraja diketuai oleh Ibu Tombe sedangkan wilayah Makassar diketuai Ibu La'lang. Pada tahun 1968 terjadilah penggabungan antara kaum perempuan di Tanah Toraja dan Makassar dengan yang diketuai Ibu La'lang.

Pada tahun itu juga diadakan Kongres Majelis Pusat dimana dalam kongres itu Ibu Karangan Mongan terpilih sebagai Ketua Biro Kaum Ibu. Menurut Buletin Super Media Komunikasi Informasi Wanita Gereja KIBAID penetapan tahun kelahiran PKW Gereja KIBAID tahun 1968 dan tanggal lahir atau berdirinya PKW diperkirakan tanggal 21 November 1968 sebab Kongres pertama Kaum perempuan dilaksanakan saat itu di Makale.

Pada awal terbentuknya organisasi Persekutuan Kaum Wanita (PKW) dinamakan Biro Kaum Ibu. Kemudian pada tahun 1972-2004 dinamakan Persekutuan Kaum Wanita (PKW) 2004-sekarang. Persekutuan Kaum Wanita Gereja Kibaid Klasis Makasar berada pada 11 Gereja Lokal dalam lingkup Klasis Makassar yang berada di Kabupaten Pangkep, Maros, Makassar yaitu (1) Gereja KIBAID Pangkep, (2) Gereja KIBAID Maros, (3) Gereja KIBAID Sudiang, (4) Gereja KIBAID Batu Bara Daya, (5) Gereja KIBAID Dirgantara, (6) Gereja KIBAID Perumnas, (7) Gereja KIBAID Balang Boddong, (8) Gereja KIBAID Lantamal, (9) Gereja KIBAID Antang, (10) Gereja KIBAID Bara Baraya, (11) Gereja KIBAID Latimojong.

Pengurus Persekutuan Kaum Wanita Gereja KIBAID periode 20082012 diketuai oleh Diaken Ny. Arryani Mongan Ampang.

\section{Jenis Penelitian}

Jenis penelitian yang digunakan adalah bersifat kuantitatif, yaitu penelitian dengan cara mengumpulkan data dari sejumlah unit atau individu dalam bentuk angket yang disajikan dalam model tabel, atau penelitian kuantitatif adalah data yang berbentuk angka. ${ }^{16}$

\footnotetext{
${ }^{15}$ Buletin, Suara Perempuan. Makassar: Perkelutuan Kaum Wanita Se Indonesia, Edisi Desember 2010.

${ }^{16}$ Sugiono, Statistika Untuk Penelitian (Bandung: CV. Alfabeta, 2007), 15.
} 


\section{Populasi dan Sampel \\ Populasi}

Menurut Sutrisno Hadi, "Populasi adalah seluruh penduduk yang dimaksudkan untuk diteliti. ${ }^{17}$ Dalam penelitian ini yang menjadi populasi adalah orang tua tunggal dan anak orang tua tunggal di Persekutuan Kaum Wanita KIBAID penulis menfokuskan pada masing-masing jemaat yang terdaftar di Persekutuan Kaum Wanita KIBAID Klasis Makassar yang terhitung 89 orang tua tunggal.

\section{Sampel}

Menurut Sutrisno Hadi, "Sampel adalah bagian dari populasi. Sampel adalah jumlah penduduk yang jumlahnya kurang dari populasi. Jadi sampel adalah bagian dari populasi atau yang mewakili secara keseluruan dari populasi, maka penelitian yang dilakukan terhadap sampel itu pada umumnya bertujuan untuk menarik kesimpulan tentang populasi. ${ }^{18}$

Berdasarkan pengertian di atas, maka yang menjadi sampel dalam tulisan ini adalah orang tua tunggal berjumlah 29 orang dan anak orang tua tunggal 29.

\section{Prosedur Penelitian}

Agar penelitian dapat mencapai sasaran yang diharapkan, maka penulis menguraikan tahap demi tahap prosedur pengumpulan data.

\section{Tahap Persiapan}

Sebelum melaksanakan penelitian maka terlebih dahulu peneliti menyusun beberapa persiapan antara lain:

\section{Penentuan Judul}

Judul yang dipilih oleh penulis adalah Peran Orang Tua Tunggal Dalam Membimbing Anak Remaja Mencapai Kualitas Hidup di Persekutuan Kaum Wanita Gereja KIBAID Klasis Makassar.

\section{Alasan Pemilihan Tempat Penelitian.}

Ada beberapa alasan mengapa penulis melakukan penelitian di Persekutuan Kaum Wanita Gereja KIBAID Klasis Makassar karena:

Pertama, penulis adalah anggota Persekutuan Kaum Wanita Gereja KIBAID Klasis Makasar

Kedua, sebagai orang tua tunggal penulis mempunyai beban sendiri untuk melihat lebih dekat pergumulan orang tua tunggal bersama anakanaknya dan berbagi pengalaman bersama.

\footnotetext{
${ }^{17}$ Sutrisno Hadi Statistik (Yogyakarta: FIP-IKIP,1975), 3.

${ }^{18}$ Sutrisno Hadi Statistik (Yogyakarta: FIP-IKIP,1975), 3
} 
Ketiga, penulis lebih mudah bersosialisasi dengan anggota persekutuan Kaum Wanita Gereja KIBAID Makassar.

Keempat, penulis tentunya telah mengetahui kebutuhan bagi jemaat Gereja KIBAID, dan telah mengamati secara langsung karena penulis sendiri telah terlibat di lapangan atau telah menjadi pengurus persekutuan Kaum Wanita Gereja KIBAID Makassar.

\section{Teknik Pengumpulan Data}

Adapun teknik pengumpulan data yang penulis lakukan adalah melalui angket (Kuesioner). Dalam pengumpulan data pendukung tulisan ini, penulis memakai angket. Angket adalah seperangkat pertanyaan yang tertulis yang diberikan kepada subjek untuk mendapatkan informasi dan responden dalam arti pribadi. ${ }^{19}$ Dalam hal ini penulis mengirimkan 29 angket untuk orang tua tunggal dan 29 angket untuk anak remaja di Persekutuan Kaum wanita Gereja KIBAID Klasis Makassar.

\section{Teknik Analisis Data}

Data yang dikumpul melalui hasil penelitian dianalisis dengan beberapa cara diantaranya:

Pertama, Dekarya ilmiah yaitu data tentang peran orang tua tunggal dalam membimbing anak remaja yang terkumpul dianalisis dengan cara menguraikan atau memaparkannya dalam bentuk kalimat.

Kedua, Deduksi Induksi yaitu data penilaian responden mengenai peran orang tua tunggal dalam membimbing anak remaja mencapai kualitas hidup di Persekutuan Kaum Wanita Gereja KIBAID Klasis Makassar diananlisis dengan cara memaparkan bukti-bukti yang ada. Berdasarkan bukti-bukti tersebut ditarik suatu kesimpulan.

Ketiga, Historis yaitu data yang terkumpul dianalisis dengan cara menjelaskan latar belakang secara singkat mengenai sejarah Gereja KIBAID. Dalam pengolahan data, penulis mengunakan program atau sofware SPSS (Statistical Product and Service Solution). Untuk menganalisis data yang terkumpul dipergunakan rumus sebagai berikut:

$$
\begin{gathered}
\mathrm{P} \\
\mathrm{N}
\end{gathered}
$$

Keterangan:

$\%=$ Presentase Pemilih

$\mathrm{P}=$ Jumlah Pemilih

$\mathrm{N}=$ Jumlah Keseluruhan Responden

\footnotetext{
${ }^{19}$ Sutrisno Hadi, Statistik (Yogyakarta: FIP-IKIP,1975), 3.
} 
Data yang terkumpul dalam penelitian angket akan dianalisis dengan cara statistika-deskriptif yang menggunakan teknik pengumpulan data dengan pengajuan kuesioner dan hasilnya akan disajikan dalam bentuk tabel.

Sedangkan data yang terkumpul dari penelitian wawancara akan dianalisis dengan cara deskriptif-kualitatif.

\section{ANALISIS HASIL PENELITIAN DAN PEMBAHASAN}

\section{Penyajian}

Bab ini membahas hasil analisis data yang meliputi deskriptif data setiap variabel, pengujian persyaratan analisis, dan pembahasan hasil penelitian lapangan.

\section{Statistics}

\begin{tabular}{|c|c|c|c|c|}
\hline & $\begin{array}{c}\text { Orang Tua } \\
\text { Tunggal }\end{array}$ & $\begin{array}{c}\text { Bimbingan Orang Tua } \\
\text { Untuk Mencapai } \\
\text { Kualitas Hidup }\end{array}$ & $\begin{array}{c}\text { Dampak Sosial } \\
\text { dan Psikologi } \\
\text { Pada Anak }\end{array}$ & $\begin{array}{c}\text { Peran } \\
\text { Gereja }\end{array}$ \\
\hline \multirow{2}{*}{ N $\quad \begin{array}{c}\text { Valid } \\
\text { Missing }\end{array}$} & 29 & 29 & 29 & 29 \\
& 0 & 0 & 0 & 0 \\
\hline
\end{tabular}

Statistik menunjukkan bahwa responden berjumlah 29 orang. Dari ke 29 orang ini semuanya dinyatakan valid.

\section{Statistik untuk Orang Tua Tunggal}

Questioner pada item pengertian dan tanggung jawab sebagai orang tua tunggal diturunkan 5 pertanyaan sebagai indikasi pokok masalah di antaranya; Pertama, Orang tua tunggal ialah mereka yang harus bekerja sekaligus membesarkan anaknya, berperan sebagai ayah dan ibu. Kedua, Orang tua tunggal atau single parent adalah mereka yang menjalani fungsi sebagai orang tua. Baik berfungsi kebagai bapak/kepala rumah tangga, yang bekerja dan mencari nafkah untuk keluarga, maupun dalam fungsi sebagai ibu yakni mendidik, membesarkan, mendampingi anak-anak dalam masa pertumbuhannya. Ketiga, Sebagai orang tua tunggal, mengharuskan seseorang untuk bisa mengatur segala seguatunya dengan seorang diri. Termasuk dalam mengatur waktu, kapan ia harus menyediakan waktu bagi anak, kapan harus bekerja, dan bagaimana mengatasi masalah. Keempat, Orang tua tunggal dalam kedudukannya sebagai kepala berarti ia sebagai kepala harus melayani, melindungi, dan menyediakan kebutuhan keluarga, 
secara singkat kewajibannya adalah mengasihi dan semuanya yang tercangkup dalam kata tersebut. Kelima, Diibratkan seperti seorang pembuat bejana, Orang tua tungga di berikan tanggung jawab untuk membentuk dan mencetak kehidupan rohani mental anak-anak mereka.

\begin{tabular}{|c|c|c|c|c|c|}
\hline \multicolumn{2}{|l|}{} & Frequency & Percent & $\begin{array}{c}\text { Valid } \\
\text { Percent }\end{array}$ & $\begin{array}{c}\text { Cumulative } \\
\text { Percent }\end{array}$ \\
\hline Valid & 75 & 6 & 20.7 & 20.7 & 20.7 \\
\hline & 85 & 1 & 3.4 & 3.4 & 24.1 \\
\hline & 90 & 8 & 27.6 & 27.6 & 51.7 \\
\hline & 95 & 5 & 17.2 & 17.2 & 69.0 \\
\hline & 100 & 9 & 31.0 & 31.0 & 100.0 \\
\hline & Total & 29 & 100.0 & 100.0 & \\
\hline
\end{tabular}

Distribusi frekuensi yang ditampilkan menunjukkan jumlah responden terendah, yaitu 6 dengan nilai skor 75, sedangkan jumlah responden tertinggi yaitu 9 dengan nilai skor 100. Pada statistik ini disertai dengan informasi tentang jumlah prosentasenya, responden dengan jumlah prosentase dari yang terendah yaitu 3.4\% sebanyak l orang, $17.2 \%$ sebanyak 5 orang, $20.7 \%$ sebanyak 6 orang, $27.6 \%$ sebanyak 8 orang, $31.0 \%$ sebanyak 9 orang. Nilai terendah antara $75-85$, dengan prosentase $3.4 \%-20.7 \%$, dan dengan frequency 7 responden. Nilai sedang antara 90, dengan prosentase $27.6 \%$, dan dengan frequency 8 responden. dan niali tertinggi antara 95-100, dengan prosentase $17.2 \%-31.0 \%$, dan dengan frequency 14 responden. Bentuk distribusi di atas dapat diketahui dari grafik histogramnya dan keruv normalnya. Dari tampilan grafik di bawah ini dapat dilihat bahwa distribusi variable item pengertian dan tanggung jawab sebagai orang tua tunggal berbentuk tidak normal atau tidak merata. Itu desebabkan faktor jumlah responden yang relatif bervariasi.

\section{Statistik Bimbingan Orang Tua untuk Mencapai Kualitas Hidup}

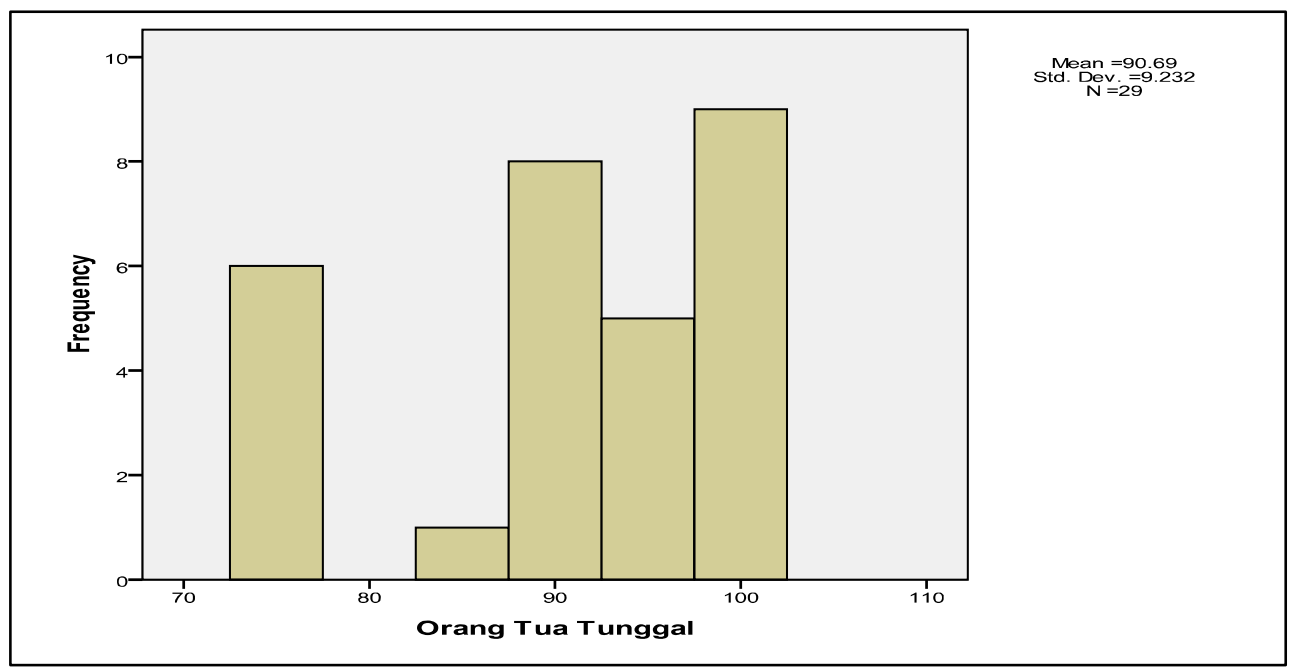


Questioner pada item bimbingan orang tua untuk mencapai kualitas hidup diturunkan 7 pertanyaan sebagai indikasi pokok masalah di antaranya; Pertama, Sebagai orang tua tunggal saya bertanggung jawab untuk kehidupan rohani anak. Mengajarkan mereka tentang kebenaran Firman Tuhan. Kedua, Sebagai orang tua tunggal saya bertanggung jawab untuk kehidupan rohani anak dalam hal mengajarkan tentang kasih Allah yang telah menyelamatkan manusia berdosa. Ketiga, Sebagai orang tua tunggal saya bertanggung jawab untuk kehidupan rohani anak dalam hal menjelaskan tentang dosa dan tentang penyediaan pengampunan karena telah mengaku dosa. Keempat, Sebagai orang tua tunggal saya bertanggung jawab untuk kehidupan rohani anak dalam hal mengajarkan tentang keselamatan dan keputusan pribadi untuk menerima Yesus sebagi Tuhan dan Juruselamat. Kelima, Sebagai orang tua tunggal saya bertanggung jawab untuk kehidupan rohani anak dalam hal mengajarkan anak untuk takut akan Tuhan, mengasihi Tuhan, dan lebih mencintai Tuhan. Keeman, Sebagai orang tua tunggal saya bertanggung jawab untuk kehidupan rohani anak dalam hal mengasihi dan hormat kepada orang tua. Ketuju, Sebagai orang tua tunggal saya bertanggung jawab untuk kehidupan rohani anak dalam hal mengasihi diri sendiri dan mengasihi sesama.

Bimbingan Orang Tua untuk Mencapai Kualitas Hidup

\begin{tabular}{|c|c|c|c|c|c|}
\hline & & Frequency & Percent & $\begin{array}{c}\text { Valid } \\
\text { Percent }\end{array}$ & $\begin{array}{c}\text { Cumulative } \\
\text { Percent }\end{array}$ \\
\hline Valid & 75.00 & 4 & 13.8 & 13.8 & 13.8 \\
\hline & 78.57 & 1 & 3.4 & 3.4 & 17.2 \\
\hline & 82.14 & 1 & 3.4 & 3.4 & 20.7 \\
\hline & 85.71 & 2 & 6.9 & 6.9 & 27.6 \\
\hline & 89.28 & 3 & 10.3 & 10.3 & 37.9 \\
\hline & 92.85 & 4 & 13.8 & 13.8 & 51.7 \\
\hline & 96.42 & 4 & 13.8 & 13.8 & 65.5 \\
\hline & 100.00 & 10 & 34.5 & 34.5 & 100.0 \\
\hline & Total & 29 & 100.0 & 100.0 & \\
\hline
\end{tabular}

Distribusi frekuensi yang ditampilkan menunjukkan jumlah responden terendah, yaitu 4 dengan nilai skor 75.00, sedangkan jumlah responden tertinggi yaitu 10 dengan nilai skor 100. Pada statistik ini disertai dengan informasi tentang jumlah prosentasenya, responden dengan jumlah prosentase dari yang terendah yaitu 3.4\% sebanyak 2 orang, $6.9 \%$ sebanyak 2 orang, $10.3 \%$ sebanyak 3 orang, $13.8 \%$ sebanyak 12 orang, $34.5 \%$ sebanyak 10 orang. Nilai terendah antara 75.00 - 82.14, dengan prosentase 3.4\% $13.8 \%$, dan dengan frequency 6 responden. Nilai sedang antara 85.71 - 89.28, dengan prosentase $6.9-10.3 \%$, dan dengan frequency 5 responden. dan nilai 
tertinggi antara 92.85-100, dengan prosentase $13.8 \%$ - 34.5\%, dan dengan frequency 18 responden. Bentuk distribusi di atas dapat diketahui dari grafik histogramnya dan keruv normalnya. Dari tampilan grafik di bawah ini dapat dilihat bahwa distribusi variable item bimbingan orang tua untuk mencapai kualitas hidup berbentuk tidak normal atau tidak merata. Itu desebabkan faktor jumlah responden yang relatif bervariasi.

Statistik untuk Dampak Sosial dan Psikologi Pada Anak

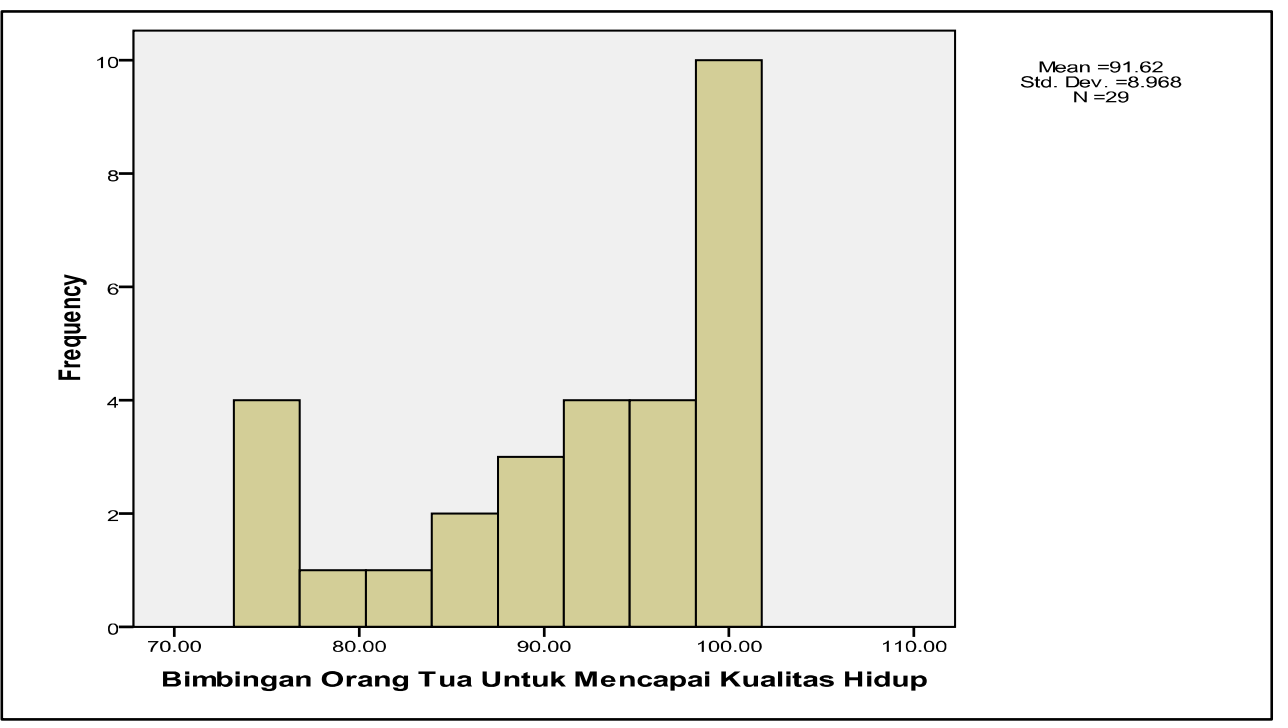

Questioner pada item dampak sosial dan psikologi pada anak diturunkan 7 pertanyaan sebagai indikasi pokok masalah di antaranya; Pertama, Sebagai orang tua tunggal saya bertanggung jawab untuk kehidupan rohani anak, terutama pada kebutuhan pada hubungan pribadinya dengan Tuhan. Kedua, Sebagai orang tua tunggal saya bertanggung jawab pada konsep penerimaan diri anak agar ia dapat menerima kenyaan hidupnya bahwa ia memiliki orang tua yang sudah tidak lengkap. Ketiga, Sebagai orang tua tunggal saya bertanggung jawab mendorong anak untuk memiliki rasa percaya diri bahwa ia pasti mampu berhasil seperti keberhasilan yang telah dicapai oleh anak-anak yang memiliki orang tua lengkap. Keempat, Sebagai orang tua tunggal saya bertanggung jawab untuk tetap menumbuhkan cinta dalam hubungan sebagai sesama anggota dalam kelurga (dalam rumah). Kelima, Sebagai orang tua tunggal saya bertanggung jawab untuk menumbuhkan rasa tanggung jawab bersama dalam kelurga, bahwa baik buruknya atau berhasil tidaknya kelurga adalah karena anggota keluarga. Keeman, Sebagai orang tua tunggal saya bertanggung jawab untuk menumbuhkan rasa percaya diri anak dalam masyarakat, tidak minder atau pun irihati kepada anak-anak 
lain yang masih lengkap orang tuanya. Ketuju, Sebagai orang tua tunggal saya bertanggung jawab untuk mendorong anak aktif dan terlibat dalam kegiatan pelayanan di gereja.

Dampak Sosial dan Psikologi Pada Anak

\begin{tabular}{|cc|c|c|c|c|}
\hline & Frequenscy & Percent & $\begin{array}{c}\text { Valid } \\
\text { percent }\end{array}$ & $\begin{array}{c}\text { Commulati } \\
\text { ve percent }\end{array}$ \\
\hline \multirow{6}{*}{ Valid } & 75.00 & 4 & 13.8 & 13.8 & 13.8 \\
& 78.57 & 3 & 10.3 & 10.3 & 24.1 \\
& 82.14 & 2 & 6.9 & 6.9 & 31.0 \\
& 85.71 & 5 & 17.2 & 17.2 & 48.3 \\
& 89.28 & 4 & 13.8 & 13.8 & 62.1 \\
& 96.42 & 6 & 20.7 & 20.7 & 82.8 \\
& 100.00 & 5 & 17.2 & 17.2 & 100.0 \\
& Total & 29 & 100.0 & 100.0 & \\
\hline
\end{tabular}

Distribusi frekuensi yang ditampilkan menunjukkan jumlah responden terendah, yaitu 4 dengan nilai skor 75.00 , sedangkan jumlah responden tertinggi yaitu 5 dengan nilai skor 100. Pada statistik ini disertai dengan informasi tentang jumlah prosentasenya, responden dengan jumlah prosentase dari yang terendah yaitu 6.9\% sebanyak 2 orang, $10.3 \%$ sebanyak 3 orang, $13.8 \%$ sebanyak 8 orang, $17.2 \%$ sebanyak 10 orang, $20.7 \%$ sebanyak 6 orang. Nilai terendah antara $75.00-78.57$, dengan prosentase $10.3 \%$ $13.8 \%$, dan dengan frequency 7 responden. Nilai sedang antara $82.14-89.28$, dengan prosentase $6.9-17.2 \%$, dan dengan frequency 11 responden. dan niali tertinggi antara $96.42-100$, dengan prosentase $17.2 \%-20.7 \%$, dan dengan frequency 11 responden. Bentuk distribusi di atas dapat diketahui dari grafik histogramnya dan keruv normalnya. Dari tampilan grafik di bawah ini dapat dilihat bahwa distribusi variable item dampak sosial dan psikologi pada anak berbentuk tidak normal atau tidak merata. Itu desebabkan faktor jumlah responden yang relatif bervariasi.

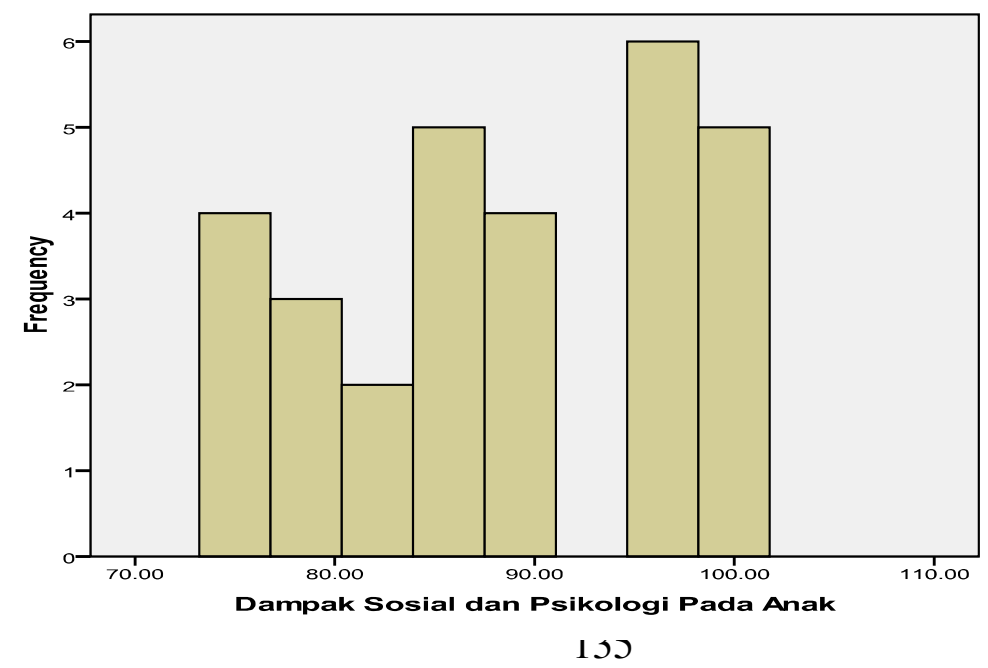

Mean $=88.42$
Std. Dev. $=8.833$
$N=29$ 


\section{Statistik untuk Peran Gereja}

Questioner pada item peran gereja terhadap perhatian pada orang tua tunggal diturunkan 8 pertanyaan sebagai indikasi pokok masalah di antaranya; Pertama, Gereja (dalam hal ini persekutuan kaum wanita) bertanggung jawab untuk senantiasa mengingat dalam doa baik secara pribadi mapuan dalam persekutuan bagi ibu-ibu yang telah di "tinggal" oleh suaminya. Kedua, Gereja (dalam hal ini persekutuan kaum wanita) bertanggung jawab untuk melakukan pelayanan perkunjunan khusu sebagai bentuk kepedulian gereja kepada ibu-ibu yang telah di "tinggal" oleh suaminya. Ketiga, Gereja (dalam hal ini persekutuan kaum wanita) bertanggung jawab pada kehidupan dan pelayanan rohani dengan melibatkannya dalam pelayanan seperti berdoa dalam persekutuan, memimpin puji-pujian bahkan memimpin renungan bagi ibu-ibu yang telah di "tinggal" oleh suaminya. Keempat, Gereja (dalam hal ini persekutuan kaum wanita) bertanggung jawab untuk menerima, memberi perhatian khusus, bahkan perlindungan sebagai saudara seiman bagi ibu-ibu yang telah di "tinggal" oleh suaminya. Kelima, Gereja (dalam hal ini persekutuan kaum wanita) bertanggung jawab untuk memberikan solusi adalam masalah finansial bagi ibu-ibu yang telah di "tinggal" oleh suaminya. Keeman, Mengatasi masalah finansialnya ialah dengan mancarikan atau memberikan lapangan pekerjaan kepada ibu-ibu yang telah di "tinggal" oleh suaminya. Ketuju, Mengatasi masalah finansialnya ialah dengan memberikan atau mengajarkan keterampilan baik itu kerajinan tangan atau memasak yang akan mendorongnya untuk berkembang dan berdikari kepada ibu-ibu yang telah di "tinggal" oleh suaminya. Kedelapan, Mengatasi masalah finansialnya ialah dengan memberi perhatian khusus melalui sumbangan sukarela pada hari raya besar gereja, seperti Natal, Paskah, dan ulang tahun gereja kepada ibu-ibu yang telah di "tinggal" oleh suaminya. 
Peran Gereja

\begin{tabular}{|c|c|c|c|c|}
\hline & Frequency & Percent & Valid Percent & $\begin{array}{c}\text { Cumulative } \\
\text { Percent }\end{array}$ \\
\hline 53.13 & 1 & 3.4 & 3.4 & 3.4 \\
62.50 & 1 & 3.4 & 3.4 & 6.9 \\
68.75 & 3 & 10.3 & 10.3 & 17.2 \\
71.88 & 3 & 10.3 & 10.3 & 27.6 \\
75.00 & 8 & 27.6 & 27.6 & 55.2 \\
78.13 & 2 & 6.9 & 6.9 & 62.1 \\
81.25 & 4 & 13.8 & 13.8 & 75.9 \\
84.34 & 3 & 10.3 & 10.3 & 86.2 \\
87.50 & 1 & 3.4 & 3.4 & 89.7 \\
90.63 & 1 & 3.4 & 3.4 & 93.1 \\
96.88 & 1 & 3.4 & 3.4 & 96.6 \\
100.00 & 1 & 3.4 & 3.4 & 100.0 \\
Total & 29 & 100.0 & 100.0 & \\
\hline
\end{tabular}

Distribusi frekuensi yang ditampilkan menunjukkan jumlah responden terendah, yaitu 1 dengan nilai skor 53.13, sedangkan jumlah responden tertinggi yaitu 1 dengan nilai skor 100. Pada statistik ini disertai dengan informasi tentang jumlah prosentasenya, responden dengan jumlah prosentase dari yang terendah yaitu 3.4\% sebanyak 6 orang, $6.9 \%$ sebanyak 2 orang, $10.3 \%$ sebanyak 9 orang, 13,8\% sebanyak 4 orang, 27,6\% sebanyak 8 orang. Nilai terendah antara $53.15-71.88$, dengan prosentase $3.4 \%-10.3 \%$, dan dengan frequency 8 responden. Nilai sedang antara 75.00 - 84.34, dengan prosentase $6.9-27.6 \%$, dan dengan frequency 17 responden. dan niali tertinggi antara 87.50-100, dengan prosentase 3.4\%, dan dengan frequency 4 responden. Bentuk distribusi di atas dapat diketahui dari grafik histogramnya dan keruv normalnya. Dari tampilan grafik di bawah ini dapat dilihat bahwa distribusi variable item peran gereja terhadap perhatian pada orang tua tunggal berbentuk tidak normal atau tidak merata. Itu desebabkan faktor jumlah responden yang relatif bervariasi. 


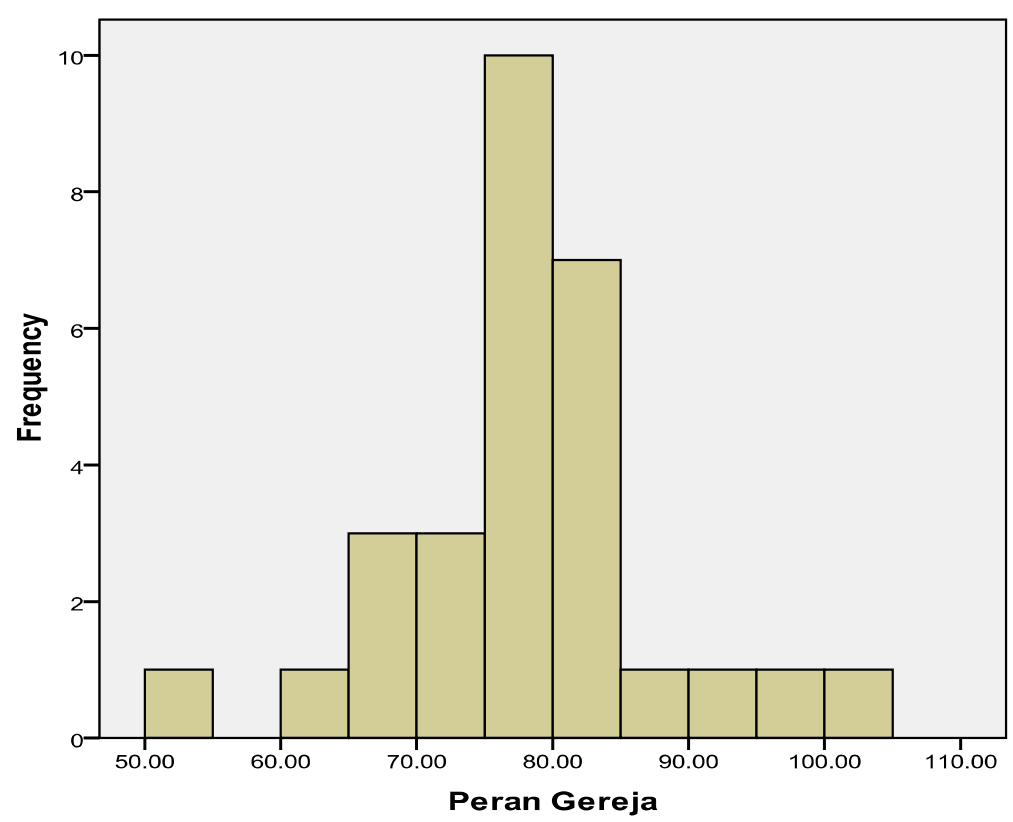

Mean $=77.48$
Std. Dev. $=9.534$
$N=29$

Correlations

\begin{tabular}{|c|c|c|c|c|}
\hline & & $\begin{array}{l}\text { Orang Tua } \\
\text { Tunggal }\end{array}$ & $\begin{array}{c}\text { Bimbingan } \\
\text { Orang Tua } \\
\text { Untuk } \\
\text { Mencapai } \\
\text { Kualitas } \\
\text { Hidup }\end{array}$ & $\begin{array}{c}\text { Dampak } \\
\text { Sosial dan } \\
\text { Psikologi } \\
\text { Pada Anak }\end{array}$ \\
\hline $\begin{array}{l}\text { Orang Tua } \\
\text { Tunggal }\end{array}$ & $\begin{array}{l}\text { Pearson } \\
\text { Correlation } \\
\text { Sig. (2-tailed) } \\
\text { N }\end{array}$ & 1 & $\begin{array}{r}.473^{* * *} \\
.010 \\
29\end{array}$ & $\begin{array}{r}.531^{* *} \\
.003 \\
29\end{array}$ \\
\hline $\begin{array}{l}\text { Bimbingan } \\
\text { Orang Tua } \\
\text { Untuk } \\
\text { Mencapai } \\
\text { Kualitas Hidup }\end{array}$ & $\begin{array}{l}\text { Pearson } \\
\text { Correlation }\end{array}$ & $.473^{* \pi}$ & 1 & $.596^{\pi *}$ \\
\hline & Sig. (2-tailed) & .010 & & .001 \\
\hline & $\mathrm{N}$ & 29 & 29 & 29 \\
\hline $\begin{array}{l}\text { Dampak Sosial } \\
\text { dan Psikologi } \\
\text { Pada Anak }\end{array}$ & $\begin{array}{l}\text { Pearson } \\
\text { Correlation } \\
\text { Sig. (2-tailed) } \\
\text { N }\end{array}$ & $\begin{array}{r}.531^{* *} \\
.003 \\
29\end{array}$ & $\begin{array}{r}.001 \\
29\end{array}$ & 29 \\
\hline
\end{tabular}

**. Correlation is significant at the 0.01 level (2-tailed). 
Arti angka hubungan

Berdasarkan dengan sasaran angka, dengan rentang nilai hubungan

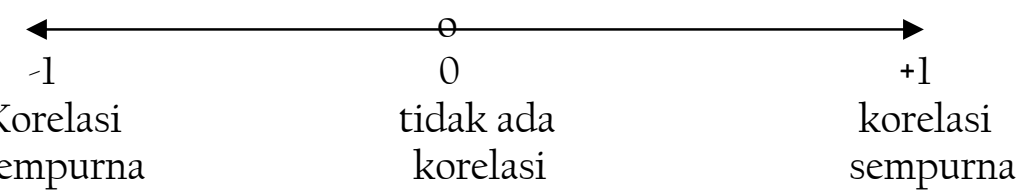

Angka-angka tersebut dijelaskan bahwa, Pertama, angka korelasi antara peran orang tua tunggal dengan bimbingan orang tua untuk mencapai kualitas hidup yang didapat 0,473 . Hal ini menunjukkan adanya hubungan yang cukup erat antara peran orang tunggal dengan bimbingan orang tua untuk mencapai kualitas hidup anak remaja. Tanda ' + ' menunjukkan bahwa semakin orang tua tunggal berperan akan memungkinkan bimbingan orang tua untuk mencapai kualitas hidup anak remaja akan tercapai. Kedua, angka korelasi antara peran orang tua tunggal dengan dampak sosial dan psikologi bimbingan untuk mencapai kualitas hidup pada anak remaja yang didapat 0,531 . Hal ini menunjukkan adanya hubungan yang cukup erat antara peran orang tua tunggal dengan dampak sosial dan psikologi bimbingan untuk mencapai kualitas hidup pada anak remaja. Tanda '+' menunjukkan bahwa semakin orang tua tunggal berperan akan memungkinkan dampak sosial dan psikologi bimbingan untuk mencapai kualitas hidup pada anak remaja akan tercapai. Ketiga, angka korelasi antara bimbingan orang tua tunggal dengan dampak sosial dan psikologi pada anak remaja untuk mencapai kualitas hidup yang didapat 0,596. Hal ini menunjukkan adanya hubungan yang cukup erat antara bimbingan orang tua tunggal dengan dampak sosial dan psikologi pada anak remaja untuk mencapai kualitas hidup. Tanda '+' menunjukkan bahwa semakin aktif orang tua tunggal dalam membimbing akan memungkinkan mempengaruhi dampak sosial dan psikologi pada anak remaja. 


\section{Sales}

- Pengertian dan Tanggung Jawab sebagai Orang Tua tunggal

- Bimbingan Orang Tua Untuk Mencapai Kualitas Hidup

- Dampak Sosial dan Psikologi Pada Anak bahwa mereka dibimbing oleh Orang Tua Tunggal

- Peran Gereja bagi Orang Tua Tunggal

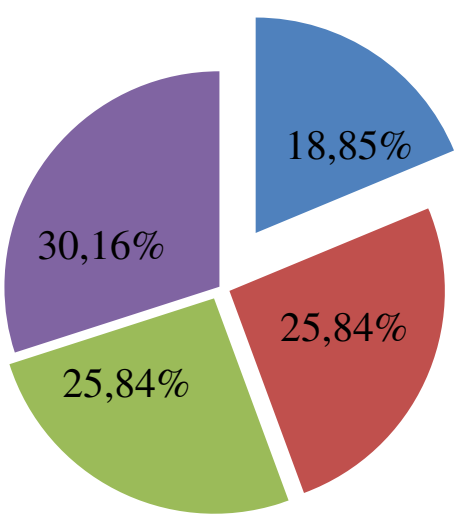

Keterangan Gambar

\begin{tabular}{|l|c|}
\hline & Sales \\
\hline Pengertian dan Tanggung Jawab sebagai Orang Tua tunggal & 18.85 \\
\hline Bimbingan Orang Tua Untuk Mencapai Kualitas Hidup & 25,84 \\
\hline $\begin{array}{l}\text { Dampak Sosial dan Psikologi Pada Anak bahwa mereka } \\
\text { dibimbing oleh Orang Tua Tunggal }\end{array}$ & 25,84 \\
\hline Peran Gereja bagi Orang Tua Tunggal & 30,16 \\
\hline
\end{tabular}

Berdasarkan hasil penelitian dari jumlah keseluruhan item yang diteliti, pengertian dan tanggung jawab sebagai orang tua tunggal menempati 18,85\%. Bimbingan orang tua untuk mencapai kualitas hidup menempati 25,84. Dampak social dan psikologi pada anak bahwa mereka dibimbing oleh orang tua tunggal menempati 25,84, dan Peran gereja bagi orang tua tunggal menempati 30,16\%. 
Jika gambar dan keterangan ini dijabarkan dalam bentuk Diagram Histogam maka di temukan gamabar dan keterangan seperti di bawah ini:

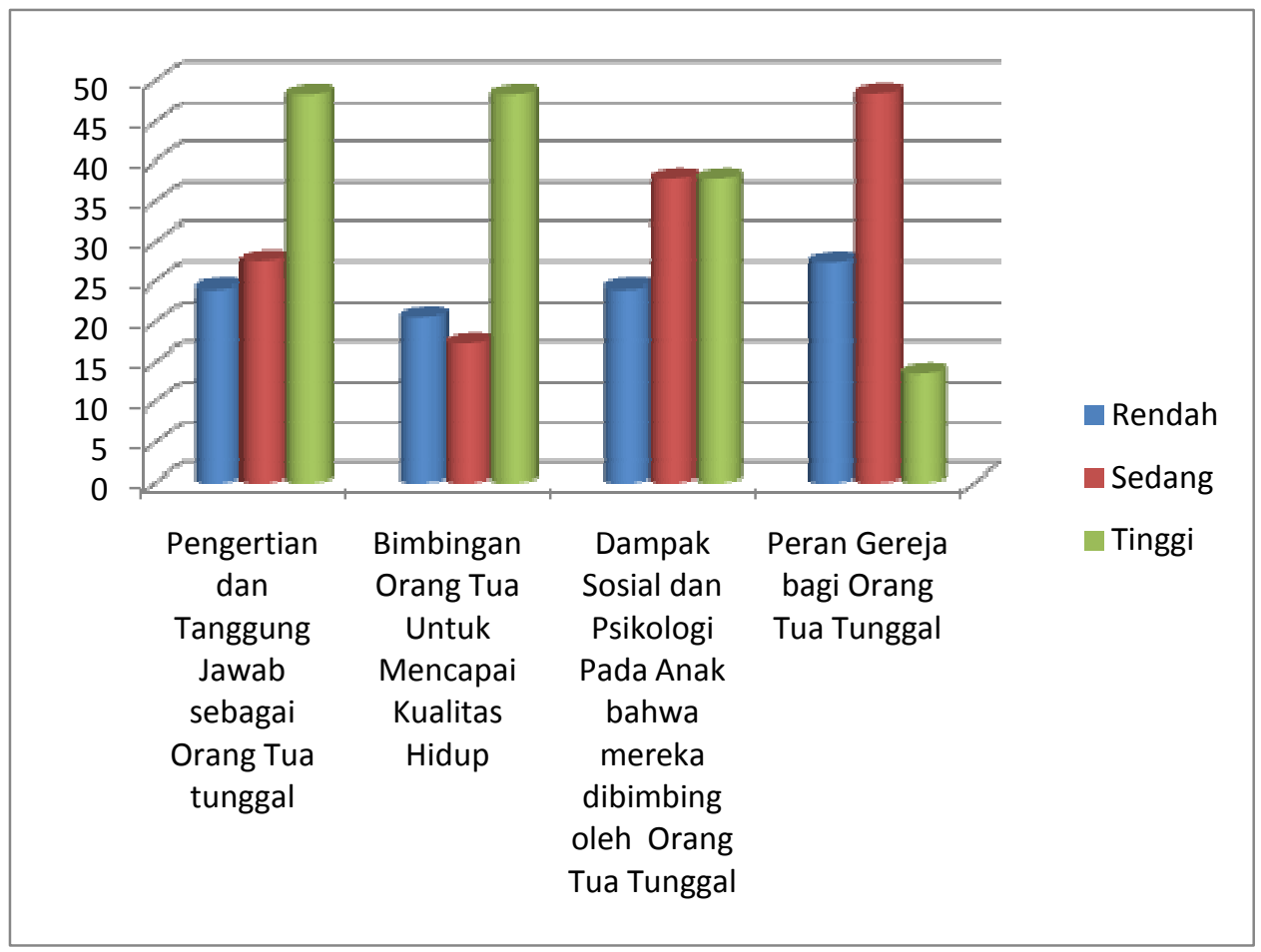

Keterangan

\begin{tabular}{|l|r|r|r|}
\hline & Rendah & Sedang & Tinggi \\
\hline $\begin{array}{l}\text { Pengertian dan Tanggung Jawab sebagai } \\
\text { Orang Tua tunggal }\end{array}$ & 24,1 & 27,6 & 48,2 \\
\hline $\begin{array}{l}\text { Bimbingan Orang Tua Untuk Mencapai } \\
\text { Kualitas Hidup }\end{array}$ & 20,6 & 17,2 & 48,2 \\
\hline $\begin{array}{l}\text { Dampak Sosial dan Psikologi Pada Anak } \\
\text { bahwa mereka dibimbing oleh Orang Tua } \\
\text { Tunggal }\end{array}$ & & & \\
\hline Peran Gereja bagi Orang Tua Tunggal & 27,4 & 48,3 & 13,6 \\
\hline
\end{tabular}

Pengertian dan Tanggung Jawab Sebagai Orang Tua tunggal

Dari $18,85 \%$ yang merupakan jumlah akumulasi semua item penelitian, terdapat nilai rendah $24,1 \%$, nilai sedang $27,6 \%$, dan nilai tertinggi $48,2 \%$ pada item pengertian dan tanggung jawab sebagai orang tua tunggal. Nilai ini sangat dipengaruhi oleh pertanyaan pertanyaan yang diajukan dalam angket penelitian, seperti pada nilai rendah ini karena 
beberapa orang tua tunggal berada hanya pada level setuju untuk pertanyaan "orang tua tunggal dalam kedudukannya sebagai kepala berarti ia sebagai kepala harus melayani, melindungi, dan menyediakan kebutuhan keluarga, secara singkat kewajibannya adalah mengasihi dan semuanya yang tercangkup dalam kata tersebut," bukan pada level sangat setuju. Selanjutnya pertanyaan "sebagai orang tua tunggal, mengharuskan seseorang untuk bisa mengatur segala sesuatunya dengan seorang diri. Termasuk dalam mengatur waktu, kapan ia harus menyediakan waktu bagi anak, kapan harus bekerja, dan bagaimana mengatasi masalah" beberapa orang tua tunggal berada pada level setuju bukan pada level sangat setuju. Namun berdasarkan jumlah akumulasi pada item ini, dapat dijelaskan bahwa rata-rata orang tua tunggal telah memiliki pengertian, dapat menjalankan tugas dan tanggung jawab sebagai orang tua tunggal.

\section{Bimbingan Orang Tua untuk Mencapai Kualitas Hidup}

Dari $25,84 \%$ yang merupakan jumlah akumulasi semua item penelitian, terdapat nilai rendah $20,6 \%$, nilai sedang $17,2 \%$, dan niali tertinggi 48,2\% pada item bimbingan orang tua untuk mencapai kualitas hidup. Nilai ini sangat dipengaruhi oleh pertanyaan pertanyaan yang diajukan dalam angket penelitian, seperti pada nilai rendah, bahkan dengan nilai prosentase yang lebih besar dari niali sedang karena beberapa orang tua tunggal berada hanya pada level setuju dan kurang setuju untuk pertanyaan "sebagai orang tua tunggal saya bertanggung jawab untuk kehidupan rohani anak dalam hal menjelaskan tentang dosa dan tentang penyediaan pengampunan karena telah mengaku dosa," bukan pada level sangat setuju. Selanjutnya pada pertanyaan "Sebagai orang tua tunggal saya bertanggung jawab untuk kehidupan rohani anak dalam hal mengasihi diri sendiri dan mengasihi sesama," dan pada pertanyaan "Sebagai orang tua tunggal saya bertanggung jawab untuk kehidupan rohani anak dalam hal mengasihi dan hormat kepada orang tua" beberapa orang tua tunggal berada pada level setuju bukan pada level sangat setuju. Namun berdasarkan jumlah akumulasi pada item ini, dapat dijelaskan bahwa ratarata orang tua tunggal telah melakukan bimbingan kepada anak-anak mereka untuk mencapai kualitas hidupnya.

\section{Dampak Sosial dan Psikologi Pada Anak Bahwa Mereka Dibimbing oleh Orang Tua Tunggal}

Dari $25.84 \%$ yang merupakan jumlah akumulasi semua item penelitian, terdapat nilai rendah $24,1 \%$, nilai sedang $37,9 \%$, dan niali tertinggi 37,9\% pada item dampak sosial dan psikologi pada anak bahwa mereka dibimbing oleh orang tua tunggal. Nilai ini sangat dipengaruhi oleh pertanyaan pertanyaan yang diajukan dalam angket penelitian, seperti pada nilai rendah ini karena beberapa orang tua tunggal berada hanya pada level 
setuju, kurang setuju, dan tidak setuju untuk pertanyaan "sebagai orang tua tunggal saya bertanggung jawab untuk menumbuhkan rasa tanggung jawab bersama dalam kelurga, bahwa baik buruknya atau berhasil tidaknya kelurga adalah karena anggota keluarga," bukan pada level sangat setuju. Selanjutnya pertanyaan "sebagai orang tua tunggal saya bertanggung jawab untuk kehidupan rohani anak, terutama pada kebutuhan pada hubungan pribadinya dengan Tuhan" pada pertanyaan "sebagai orang tua tunggal saya bertanggung jawab pada konsep penerimaan diri anak agar ia dapat menerima kenyaan hidupnya bahwa ia memiliki orang tua yang sudah tidak lengkap" dan pada pertanyaan "sebagai orang tua tunggal saya bertanggung jawab untuk menumbuhkan rasa percaya diri anak dalam masyarakat, tidak minder atau pun iri hati kepada anak-anak lain yang masih lengkap orang tuanya" beberapa orang tua tunggal berada pada level setuju bukan pada level sangat setuju. Namun berdasarkan jumlah akumulasi pada item ini, dapat dijelaskan bahwa rata-rata orang tua tunggal telah mengeti peran dan tanggung jawabnya atas dampak sosial dan psikologi pada anak bahwa mereka dibimbing oleh orang tua tunggal.

\section{Peran Gereja bagi Orang Tua Tunggal}

Dari $30,16 \%$ yang merupakan jumlah akumulasi semua item penelitian, terdapat nilai rendah $27,4 \%$, nilai sedang $48,3 \%$, dan niali tertinggi $13,6 \%$ pada item peran gereja bagi orang tua tunggal. Nilai ini sangat dipengaruhi oleh pertanyaan pertanyaan yang diajukan dalam angket penelitian, seperti pada nilai rendah ini karena beberapa orang tua tunggal berada hanya pada level setuju, kurang setuju, dan tidak setuju untuk pertanyaan "mengatasi masalah finansialnya ialah dengan memberi perhatian khusus melalui sumbangan sukarela pada hari raya besar gereja, seperti Natal, Paskah, dan ulang tahun gereja kepada ibu-ibu yang telah di 'tinggal' oleh suaminya.," bukan pada level sangat setuju. Selanjutnya pertanyaan "mengatasi masalah finansialnya ialah dengan mancarikan atau memberikan lapangan pekerjaan kepada ibu-ibu yang telah di 'tinggal' oleh suaminya." pada pertanyaan "Gereja (dalam hal ini persekutuan kaum wanita) bertanggung jawab untuk memberikan solusi adalam masalah finansial bagi ibu-ibu yang telah di 'tinggal' oleh suaminya." pada pertanyaan "Gereja (dalam hal ini persekutuan kaum wanita) bertanggung jawab pada kehidupan dan pelayanan rohani dengan melibatkannya dalam pelayanan seperti berdoa dalam persekutuan, memimpin puji-pujian bahkan memimpin renungan bagi ibu-ibu yang telah di 'tinggal' oleh suaminya." pada pertanyaan "Gereja (dalam hal ini persekutuan kaum wanita) bertanggung jawab untuk senantiasa mengingat dalam doa baik secara pribadi mapuan dalam persekutuan bagi ibu-ibu yang telah di "tinggal" oleh suaminya" dan pada pertanyaan "Mengatasi masalah finansialnya ialah dengan memberikan atau mengajarkan keterampilan baik 
itu kerajinan tangan atau memasak yang akan mendorongnya untuk berkembang dan berdikari kepada ibu-ibu yang telah di "tinggal" oleh suaminya" beberapa orang tua tunggal berada pada level setuju, kurang setuju bukan pada level sangat setuju. Oleh karenanya berdasarkan jumlah akumulasi pada item ini, dapat ditemukan bahwa rata-rata orang tua tunggal menyatakan belum merasakan adanya peran gereja bagi keberlangsungan hidup mereka dan kepedulian mereka sebagai orang tua tunggal.

\section{PENUTUP}

Pada bagian penutup dari karya tulis ini, penulis membuat kesimpulan dan memberikan saran-saran yang berhubungan dengan bagaimana peran orang tua tunggal dalam membimbing anak remaja untuk mencapai kualitas hidup.

\section{Kesimpulan}

Berdasarkan pembahasan penulis di atas, maka dapat dibuat kesimpulan sebagai berikut:

Pertama, orang tua tunggal atau single parent Persekutuan Kaum Wanita KIBAID Klasis Makassar adalah mereka yang menyadari sepenuhnya tugas mereka sebagai orang tua yang berperan sebagai ayah dan juga ibu yang mengatur segala sesuatunya di rumah dan bertanggung jawab sepenuhnya kepada anak-anak mereka.

Kedua, Orang Tua tunggal atau single parent Persekutuan Kaum Wanita KIBAID Klasis Makassar sudah sangat baik dalam menjalankan fungsinya sebagai orang tua tunggal bagi anak-anaknya. Sehingga anakanak bertumbuh dengan baik dalam mencapai kualitas hidup mereka.

Ketiga, Orang tua tunggal atau single parent Persekutuan Kaum Wanita KIBAID Klasis Makassar sangat bertanggung jawab untuk membangkitkan rasa percaya diri anak, sehingga mereka tidak minder atau iri hati kepada anak-anak lainnya yang masih memiliki orang tua yang lengkap.

Keempat, Orang tua tunggal atau single parent Persekutuan Kaum Wanita KIBAID Klasis Makassar menyadari bahwa gereja belum sepenuhnya peduli terhadap kebutuhan rohani dan financial mereka sebagai orang tua tunggal.

\section{Saran-Saran}

Pertama, sebagai orang tua tunggal harus terus mengembangkan percaya diri dalam menjalankan perannya dengan bertanggung jawab 
penuh dalam membimbing dan memotivasi anak mencapai kualitas hidupnya.

Kedua, diharapkan kepada setiap orang tua tunggal agar bisa bekerja sama dengan anak-anak mereka dan sebaliknya anak juga bekerja sama dengan orang tua agar mencapai kualitas hidup.

Ketiga, disarankan kepada Gereja dalam hal ini persekutuan Kaum Wanita Gereja KIBAID Klasis Makassar meningkatkan pelayanan secara khusus bagi orang tua tunggal agar kebutuhan rohani dan kebutuhan financial mereka dapat terpenuhi dan teratasi bagi mereka yang sangat membutuhkan. 


\section{KEPUSTAKAAN}

Archibald D. Hart, Menolong Anak Korban Perceraian. Bandung: Kalam Hidup, 2002.

Archibald D. Hart, Menolong Anak Korban Perceraian. Bandung: Kalam Hidup, 2002.

Arti kata.com, Definisi Kepustakaan, diakses tanggal 20 Mei 20ll, tersedia di http:/www.artikata.com/arti-342618-observasi.html.

Arti kata.com, Definisi Kepustakaan, diakses tanggal 26 Juni 2011 tersedia di http://www.artikata.com/ arti-37472l-kepustakaan.html.

Arti kata.com, Definisi Kepustakaan, diakses tanggal 26 Juni 2011 tersedia di http://www.artikata. com/ arti-374721-kepustakaan.html.

Arti kata.com, Definisi Kepustakaan, diakses tanggal 26 Juni 201l, tersedia di http://www.artikata.com/arti-319650-artikel.html.

Buletin, Suara Perempuan. Makassar: Perkelutuan Kaum Wanita Se Indonesia, Edisi Desember 2010.

Christella Ds, Sendiri Tidak Sepi. Denpasar: Yayasan Ave Maris Stella, April 2010).

Ibid. tersedia di http://www.artikata. com/arti-356604-wawancara.html. Ibid. tersedia di http://www.artikata. com/arti-356604-wawancara.html. Ibid. tersedia di http://www.artikata.com/arti-31904l-angket.html.

Manati Zega, Spritual Insight, Bahana, Mei 2010.

Manati Zega, Spritual Insight, Bahana, Mei, 2010.

Sugiono, Statistika Untuk Penelitian (Bandung: CV. Alfabeta, 2007).

Surya Kusuma, Bila Terpaksa Menjasi Single Parent. Jakarta: Bahana, Mei 2010

Sutrisno Hadi Statistik (Yogyakarta: FIP-IKIP,1975) 